\title{
Gene/longevity association studies at four autosomal loci (REN, THO, PARP, SOD2)
}

\author{
G De Benedictis ${ }^{1}$, L Carotenuto ${ }^{2}, \mathrm{G}$ Carrieri $^{1}, \mathrm{M}$ De L uca ${ }^{1,3}, \mathrm{E} \mathrm{Falcone}^{1}, \mathrm{G}$ R ose $^{1}$, S

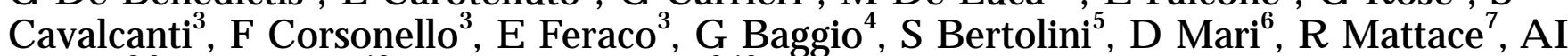 \\ Yashin ${ }^{8,9}, M$ B onafè ${ }^{10}$ and C Franceschi ${ }^{3,10}$ \\ ${ }^{1}$ Cell Biology D epartment, U niversity of Calabria \\ ${ }^{2} \mathrm{D}$ epartment of E lectronics, Information and Systems Sciences, U niversity of Calabria \\ ${ }^{3}$ I talian National Research Center on A ging (INRCA), A ncona and Cosenza \\ ${ }^{4} \mathrm{C}$ hair of G eriatrics, University of Sassari \\ ${ }^{5} \mathrm{~A}$ therosclerosis Prevention Center, Internal M edicine D epartment, U niversity of G enova \\ 6 Institute of Internal M edicine, IRCCS M aggiore H ospital, U niversity of M ilano \\ ${ }^{7}$ Chair of G eriatrics, U niversity of Catanzaro, I taly \\ ${ }^{8} \mathrm{M}$ ax Planck Institute for D emographic Research, R ostock, G ermany \\ ${ }^{9}$ D uke University, Centre for D emographic Studies, USA \\ ${ }^{10}$ D epartment of B iomedical Sciences, U niversity of M odena, I taly
}

\begin{abstract}
The possibility that four loci (REN, THO, PARP, SOD2) are associated with longevity was explored by comparing the genotypic pools of subjects older than $\mathbf{1 0 0}$ years with those of younger subjects matched for sex and geographic area (northern and southern Italy). The markers (all located within the respective gene) were HUMREN4; HUMTHO1; HUMPARP (gt)845nt; SOD2(C/ $T)_{401 n t}$ In order to reduce the number of genotypes, multiallelic polymorphisms were recoded as diallelic according to allele size and frequency patterns (small: S, and large: L, alleles). A significant loss of LL homozygous genotypes was found at the THO locus in male but not in female centenarians with respect to matched controls. On the other hand no significant difference was found between case/control genotypic frequencies at REN, PARP, SOD2 loci. The latter loci therefore do not affect inter-individual variability in life expectancy (at least in terms of qualitative variants associated with the tested markers). However, the data is consistent with an association between the THO locus and longevity.
\end{abstract}

Keywords: human longevity; REN; THO; PARP; SOD2

\section{Introduction}

The number of genes which could affect inter-individual variability in human life-span is expected to be high $^{1}$ and probably the majority affect longevity by

Correspondence: G De Benedictis, Department of Cell B iology, U niversity of Calabria, A rcavacata. 87030 R ende. Italy. Fax: +39 9844929 11; E mail: g.debenedictis@unical.it R eceived 4 D ecember 1997; revised $11 \mathrm{M}$ arch 1998; accepted 15 A pril 1998 altering the risk of death at various ages. ${ }^{2}$ O ne approach to identifying some of these genes is a comparative analysis at candidate loci between gene pools of extremely elderly individuals and younger people from the same population. ${ }^{3}$ However, in this approach, special attention must be paid to case/control matching. This is particularly important when studies on Italian people are carried out, not only because different genetic components are present in the I talian gene pool, ${ }^{4}$ but also because migrations from southern 
to northern Italy due to social and economic factors occurred in the last century. We have therefore planned a research project in which polymorphic markers at candidate loci were compared between centenarians and younger people, whose ancestry in the specific geographic area was checked back as far as the grandparents' generation.

Four autosomal genes, which code for proteins involved in fundamental metabolic pathways, were chosen as candidate loci. The genes were renin (REN), tyrosine hydroxylase (THO), poly(A DP-ribose) polymerase (PARP) and superexidodismutase 2 (SO D 2).

The REN gene (9 exons; 1q32 chromosome) codes for renin, an aspartylprotease which catalyses the first step of the biosynthetic cascade leading to angiotensin II. A n (acag)n repeat polymorphic region ${ }^{5}$ lies in intron 7 (H U M REN 4 marker). The five known alleles, designated from 8 to 12 according to the repeat number (allele 9 is absent in Caucasians), show bimodal frequency distribution, with peaks at 8 and 11 repeats. ${ }^{6}$

The THO gene (14 exons; 11p15.5 chromosome) codes for tyrosine hydroxylase, the rate-limiting enzyme for synthesis of catecholamines, aminoacidderived molecules which act both as hormone (adrenalin) and neurotransmitters (dopamine and noradrenalin). By alternative splicing of the TH O transcript, four types of mRNA are produced, which differ in the inclusion or exclusion of exon 2 in the spliced products. ${ }^{7}$ Specifically in intron 1 an (aagt) $n$ repeat polymorphism (HUM THO 1) is located, ${ }^{8}$, with 8 alleles varying from 5 to 11 repeats (two alleles have 10 repeats; one of them, 10-1 allele, lacks a single a). A llele frequency distribution is bimodal, with peaks at 6 and 10-1 repeats. ${ }^{9}$ HUMTHO 1 alleles are in linkage disequilibrium with I NS-V NTR alleles ${ }^{10,11}$ which affect the levels of insulin transcription differently in pancreas ${ }^{12,13}$ and thymus. ${ }^{14,15}$

The PARP gene (23 exons, 1q41-42 chromosome) codes for a zinc finger nuclear enzyme which is strongly activated by DNA breaks and promotes DNA repair. ${ }^{16}$ PARP activity is positively correlated with speciesspecific life span in mammalian species. ${ }^{17,18,19} \mathrm{~A}$ (gt)n repeat polymorphism lies in exon $1 .^{20}$ The known six alleles, designated according to size ( $85 \mathrm{bp}-99 \mathrm{bp}$ size range), show bimodal frequency distribution, with peaks at $85 \mathrm{bp}$ and $93 \mathrm{bp}$ alleles.

SOD 2 is a manganese-containing enzyme which is coded by a nuclear gene ( $6 \mathrm{q} 25$ chromosom) and is posttranslationally imported into the mitochondrial matrix. ${ }^{21} \mathrm{H}$ ere SOD2 rapidly converts superoxide radicals into $\mathrm{H}_{2} \mathrm{O}_{2}$ which is further detoxified by catalase and glutathione peroxidase. A structural t to $\mathrm{c}$ substitution in the mitochondrial targeting domain has recently been described ${ }^{22,23}$ which changes valine ${ }_{16}$ to alanine $_{16}$ thus modulating the efficiency of mitochondrial transport. ${ }^{23}$

\section{Materials and Methods}

\section{Samples}

B oth centenarians and controls were clinically healthy unrelated subjects from various socio-economic backgrounds. $B$ irth and residence of each individual in the specific geographic area (northern or southern Italy) was checked back as far as the grandparents' generation. A II individuals gave informed consent prior to their inclusion in the study.

Centenarians 0 nly individuals who were over 100 years old on the day the blood was taken were included in the study. The oldest subject was a 109 -year-old woman; 109 subjects ( 83 females and 26 males) were from northern I taly (L ombardia, Veneto, Liguria, E milia-R omagna) and 87 subjects (60 females and 27 males) were from southern Italy (Sicilia, Calabria, Campania, Puglia).

Controls The ages of the control group ranged from 10 to 85 years (median ages 41 and 31 years in northern and southern Italian samples, respectively); 119 subjects (70 females and 49 males) were from northern Italy and 239 subjects ( 126 females and 113 males) were from southern Italy, from the regions listed above. The individuals aged from 10 to 18 years were children from primary and secondary schools, whilst the others were volunteer donors (chiefly undergraduate students and U niversity staff) invited to take part in the study by an appropriate campaign. A total of eight sub-samples were obtained, arranged by age (centenarians/ controls), sex (males/females) and geographic area (northern/ southern I taly).

\section{Genotypic Typing}

DNAs were extracted from blood buffy-coats following standard procedures.

HUMREN 4 and HUMTHO 1 typings were carried out by PCR co-amplification of the DNA target sequences. ${ }^{9} \mathrm{~A}$ lleles were detected by silver staining. $\mathrm{H}$ ome-made allele ladders were used as size markers. The quality of the ladder was tested by comparison with a standard ladder kindly donated by D r C Previderè, U niversity of Pavia. A lleles were designed according to the repeat number. ${ }^{9}$ PARP (gt)n845nt $^{\text {polymor- }}$ phism was typed on PCR-amplified DNA products ${ }^{20}$ stained by silver. Home-made allele ladders were used as size markers.

$(t / c)_{401 n t}$ SOD 2 polymorphism was investigated by an original ARM S-PCR assay. PCR reaction was carried out in a $25 \mu \mathrm{l}$ volume containing $80 \mathrm{ng}$ genomic DNA, $0.5 \mu \mathrm{m}$ of a sense primer specific for either c (5'gcaggcagctggctccgac3') or t ( $5^{\prime}$ gcaggcagctggctccgat3') at nucleotide +401 and an antisense primer (5'acgcctcctggtacttctcc $\left.3^{\prime}\right), 200 \mu \mathrm{m}$ of each dNTP, 1.5U Taq polymerase, $1 \times$ Taq polymerase buffer under the 
Table 1 REN locus. G enotypic numbers and relative frequencies of the HU M RE N 4 polymorphism recoded as diallelic

\begin{tabular}{|c|c|c|c|c|c|c|c|}
\hline N orth I taly & & & & $M$ ales & & & \\
\hline G enotypes & & $\begin{array}{l}\text { Controls } \\
(n=50)\end{array}$ & & & $\begin{array}{l}\text { Centenarians } \\
(n=24)\end{array}$ & & $P$ \\
\hline & No. & Rel. freq & St. err & No. & Rel. freq & St. err & \\
\hline $\begin{array}{l}\text { SS } \\
\text { SL } \\
\text { LL }\end{array}$ & $\begin{array}{r}21 \\
28 \\
1\end{array}$ & $\begin{array}{l}0.420 \\
0.560 \\
0.020\end{array}$ & $\begin{array}{l}0.070 \\
0.070 \\
0.020\end{array}$ & $\begin{array}{r}15 \\
7 \\
2\end{array}$ & $\begin{array}{l}0.625 \\
0.292 \\
0.083\end{array}$ & $\begin{array}{l}0.100 \\
0.093 \\
0.056\end{array}$ & $\begin{array}{l}0.137 \\
0.046 \\
0.213\end{array}$ \\
\hline & & & & Eemale & & & \\
\hline G enotypes & & $\begin{array}{l}\text { Controls } \\
(n=76)\end{array}$ & & & $\begin{array}{l}\text { Centenarians } \\
(n=83)\end{array}$ & & $P$ \\
\hline & No. & Rel. freq & St. err & No. & Rel. freq & St. err & \\
\hline $\begin{array}{l}\text { SS } \\
\text { SL } \\
\text { LL }\end{array}$ & $\begin{array}{r}44 \\
28 \\
4\end{array}$ & $\begin{array}{l}0.579 \\
0.368 \\
0.053\end{array}$ & $\begin{array}{l}0.057 \\
0.055 \\
0.026\end{array}$ & $\begin{array}{r}54 \\
25 \\
4\end{array}$ & $\begin{array}{l}0.651 \\
0.301 \\
0.048\end{array}$ & $\begin{array}{l}0.052 \\
0.050 \\
0.023\end{array}$ & $\begin{array}{l}0.328 \\
0.406 \\
0.711\end{array}$ \\
\hline South I taly & & & & $M$ ales & & & \\
\hline G enotypes & & $\begin{array}{l}\text { Controls } \\
(n=38)\end{array}$ & & & $\begin{array}{l}\text { Centenarians } \\
(n=14)\end{array}$ & & $P$ \\
\hline & No. & Rel. freq & St. err & No. & Rel. freq & St. err & \\
\hline $\begin{array}{l}\text { SS } \\
\text { SL } \\
\text { LL }\end{array}$ & $\begin{array}{r}20 \\
16 \\
2\end{array}$ & $\begin{array}{l}0.526 \\
0.421 \\
0.053\end{array}$ & $\begin{array}{l}0.081 \\
0.080 \\
0.036\end{array}$ & $\begin{array}{r}10 \\
4 \\
0\end{array}$ & $\begin{array}{l}0.714 \\
0.286 \\
0\end{array}$ & $\begin{array}{l}0.121 \\
0.121 \\
0\end{array}$ & $\begin{array}{l}0.344 \\
0.524 \\
1\end{array}$ \\
\hline & & & & Female & & & \\
\hline G enotypes & & $\begin{array}{l}\text { Controls } \\
(n=54)\end{array}$ & & & $\begin{array}{l}\text { Centenarians } \\
(n=36)\end{array}$ & & $P$ \\
\hline & $\mathrm{No}$. & Rel. freq & St. err & No. & Rel. freq & St. err & \\
\hline $\begin{array}{l}\text { SS } \\
\text { SL } \\
\text { LL }\end{array}$ & $\begin{array}{r}27 \\
24 \\
3\end{array}$ & $\begin{array}{l}0.500 \\
0.444 \\
0.056\end{array}$ & $\begin{array}{l}0.068 \\
0.068 \\
0.031\end{array}$ & $\begin{array}{r}20 \\
15 \\
1\end{array}$ & $\begin{array}{l}0.556 \\
0.417 \\
0.028\end{array}$ & $\begin{array}{l}0.083 \\
0.082 \\
0.027\end{array}$ & $\begin{array}{l}0.670 \\
0.831 \\
0.624\end{array}$ \\
\hline
\end{tabular}

S: alleles 7 and $8 ; L:$ alleles 10, 11, 12. P: probability of falsely rejecting the hypothesis of equal genotype frequency (SS or SL or $L L)$ in centenarians and controls $\alpha=0.017$.

following conditions. $1 \mathrm{~min}$ at $94^{\circ} \mathrm{C}, 21$ cycles at $94^{\circ} \mathrm{C}$ for $25 \mathrm{~s}$, $60^{\circ} \mathrm{C}$ for $45 \mathrm{~s}, 72^{\circ} \mathrm{C}$ for $30 \mathrm{~s}, 9$ cycles at $94^{\circ} \mathrm{C}$ for $25 \mathrm{~s}, 55^{\circ} \mathrm{C}$ for $1 \mathrm{~min}, 72^{\circ} \mathrm{C}$ for $2 \mathrm{~min}$. A mplification products ( $\left.15 \mu \mathrm{l}\right)$ were detected by ethidium bromide staining after $2 \%$ agarose gel electrophoresis.

\section{Statistical Analysis}

A llele frequencies were computed by counting genes from the observed genotypes and allele frequency distributions were examined. A ccording to allele size and major frequency peaks, each multiallelic system (REN, THO, PARP) was recoded as a diallelic system by grouping the alleles into two classes (small: $S$ and large: $L$ alleles). All the following analyses were carried out on such recoded systems.

E xact tests were applied on each polymorphism to verify $\mathrm{H}_{\text {ardy-Weinberg equilibrium }}{ }^{4}$ in each of the eight subsamples.

The presence of interactions among the three factors genotype/sex/geographic area - within each sample (cen- tenarians; controls) was tested by log-linear analysis of the respective three-way tables. ${ }^{25}$ The frequency of each genotype was compared between centenarians and controls matched for sex and geographic area by Fisher exact tests. To reject at level $\alpha^{\prime}=0.05$ the null hypothesis that no genotypic frequency difference existed between centenarians and controls of specified sex and geographic area, the $p$ values of the three individual tests were compared against $\alpha=1-\left(1-\alpha^{\prime}\right)^{1 / 3}=0.017$.

\section{Results}

Both centenarians and controls showed the known bimodal allele frequency patterns at (REN, THO and PARP loci. A ccording to these patterns, alleles were 
Table 2 THO locus. G enotypic numbers and relative frequencies of the HUM THO 1 polymorphism recoded as diallelic

\begin{tabular}{|c|c|c|c|c|c|c|c|}
\hline \multirow{2}{*}{$\begin{array}{l}\text { North I taly } \\
\text { G enotypes }\end{array}$} & \multicolumn{7}{|c|}{ M ales } \\
\hline & & $\begin{array}{l}\text { Controls } \\
(n=49)\end{array}$ & & & $\begin{array}{l}\text { Centenarians } \\
(n=26)\end{array}$ & & $P$ \\
\hline & No. & Rel. freq & St. err & No. & Rel. freq & St. err & \\
\hline $\begin{array}{l}\text { SS } \\
\text { SL } \\
L L\end{array}$ & $\begin{array}{l}17 \\
20 \\
12\end{array}$ & $\begin{array}{l}0.347 \\
0.408 \\
0.245\end{array}$ & $\begin{array}{l}0.068 \\
0.070 \\
0.061\end{array}$ & $\begin{array}{r}10 \\
15 \\
1\end{array}$ & $\begin{array}{l}0.385 \\
0.577 \\
0.038\end{array}$ & $\begin{array}{l}0.095 \\
0.097 \\
0.038\end{array}$ & $\begin{array}{l}0.803 \\
0.225 \\
0.027\end{array}$ \\
\hline \multicolumn{8}{|c|}{ Females } \\
\hline \multirow[t]{2}{*}{ G enotypes } & & $\begin{array}{l}\text { Controls } \\
(n=70)\end{array}$ & & & $\begin{array}{l}\text { Centenarians } \\
(n=83)\end{array}$ & & $P$ \\
\hline & No. & Rel. freq & St. err & No. & Rel. freq & St. err & \\
\hline $\begin{array}{l}\text { SS } \\
\text { SL } \\
\text { LL }\end{array}$ & $\begin{array}{l}15 \\
38 \\
17 \\
\end{array}$ & $\begin{array}{l}0.214 \\
0.543 \\
0.243\end{array}$ & $\begin{array}{l}0.049 \\
0.059 \\
0.051\end{array}$ & $\begin{array}{l}14 \\
48 \\
21 \\
\end{array}$ & $\begin{array}{l}0.169 \\
0.578 \\
0.253\end{array}$ & $\begin{array}{l}0.041 \\
0.054 \\
0.048\end{array}$ & $\begin{array}{l}0.537 \\
0.744 \\
0.994 \\
\end{array}$ \\
\hline \multicolumn{4}{|l|}{ South I taly } & $M$ ales & & & \\
\hline \multirow[t]{2}{*}{ G enotypes } & & $\begin{array}{l}\text { Controls } \\
(n=113)\end{array}$ & & & $\begin{array}{l}\text { Centenarians } \\
(n=27)\end{array}$ & & $P$ \\
\hline & No. & Rel. freq & St. err & No. & Rel. freq & St. err & \\
\hline $\begin{array}{l}\text { SS } \\
\text { SL } \\
\text { LL }\end{array}$ & $\begin{array}{l}33 \\
56 \\
24\end{array}$ & $\begin{array}{l}0.292 \\
0.496 \\
0.212\end{array}$ & $\begin{array}{l}0.043 \\
0.047 \\
0.038\end{array}$ & $\begin{array}{r}10 \\
17 \\
0\end{array}$ & $\begin{array}{l}0.370 \\
0.630 \\
0\end{array}$ & $\begin{array}{l}0.093 \\
0.093 \\
0\end{array}$ & $\begin{array}{l}0.488 \\
0.284 \\
0.004\end{array}$ \\
\hline LL & \multicolumn{7}{|c|}{ Females } \\
\hline \multirow[t]{2}{*}{ G enotypes } & & $\begin{array}{l}\text { Controls } \\
(n=126)\end{array}$ & & & $\begin{array}{l}\text { Centenarians } \\
(n=60)\end{array}$ & & $P$ \\
\hline & No. & Rel. freq & St. err & No. & Rel. freq & St. err & \\
\hline $\begin{array}{l}\text { SS } \\
\text { SL } \\
L L\end{array}$ & $\begin{array}{l}48 \\
64 \\
14\end{array}$ & $\begin{array}{l}0.381 \\
0.508 \\
0.111\end{array}$ & $\begin{array}{l}0.043 \\
0.044 \\
0.028\end{array}$ & $\begin{array}{l}20 \\
26 \\
14\end{array}$ & $\begin{array}{l}0.333 \\
0.433 \\
0.233\end{array}$ & $\begin{array}{l}0.061 \\
0.064 \\
0.055\end{array}$ & $\begin{array}{l}0.626 \\
0.352 \\
0.047\end{array}$ \\
\hline
\end{tabular}

S: alleles 6, 7 and 8; L: alleles 9, 10-1, and 10. P: probability of falsely rejecting the hypothesis of equal genotype frequency (SS or $S L$ or $L L$ ) in centenarians and controls $\alpha=0.017$.

grouped as follows. Locus RE N: 7, 8 small (S) alleles; 10,11,12 large (L) alleles. L ocus TH 0: 6, 7, 8 small (S) alleles; 9, 10-1, 10 large (L) alleles. Locus PA R P: 85, 87, 89 small (S) alleles; 93, 95, 97, 99 large (L) alleles.

The observed genotypes of the recoded systems, as well as those of the SO D 2 diallelic system, are reported in Table 1, Table 2, Table 3, Table4. They were in agreement $(P>0.05)$ with those expected at $\mathrm{H}$ ardyWeinberg equilibrium in every sub-sample at each locus, except for male centenarians at the THO locus $(P=0.028)$ in southern Italy. Direct comparisons between genotypes in centenarians and controls matched for sex and geographic area (last column of Table 1, Table 2, Table 3, Table 4) showed sex-specific TH O locus/longevity association. A loss of homozygous
LL genotypes was observed in male centenarians (Table 2). The loss was statistically significant ( $P=0.004$ with $\alpha=0.017)$ in southern I taly and had borderline significance $(P=0.027)$ in northern Italy. On the contrary, no significant case/control difference was found at loci REN (Table 1), PARP (Table3) and SOD 2 (Table 4). A $n$ analysis of interactions between genotypes/sex/geographic area within both the sample selected for longevity and the controls confirmed the peculiarity observed at the THO locus. The geographic factor interacted with genotypic frequencies in controls $(P=0.040)$ but not in centenarians $(P=0.142)$, while sex strongly interacted with the genotypic frequencies in centenarians $(P=0.0002)$ but not in controls $(P=0.083)$. These findings suggested that: 
Table 3 PA R P locus. G enotypic numbers and relative frequencies of the PA R P (gt)n polymorphism recoded as diallelic

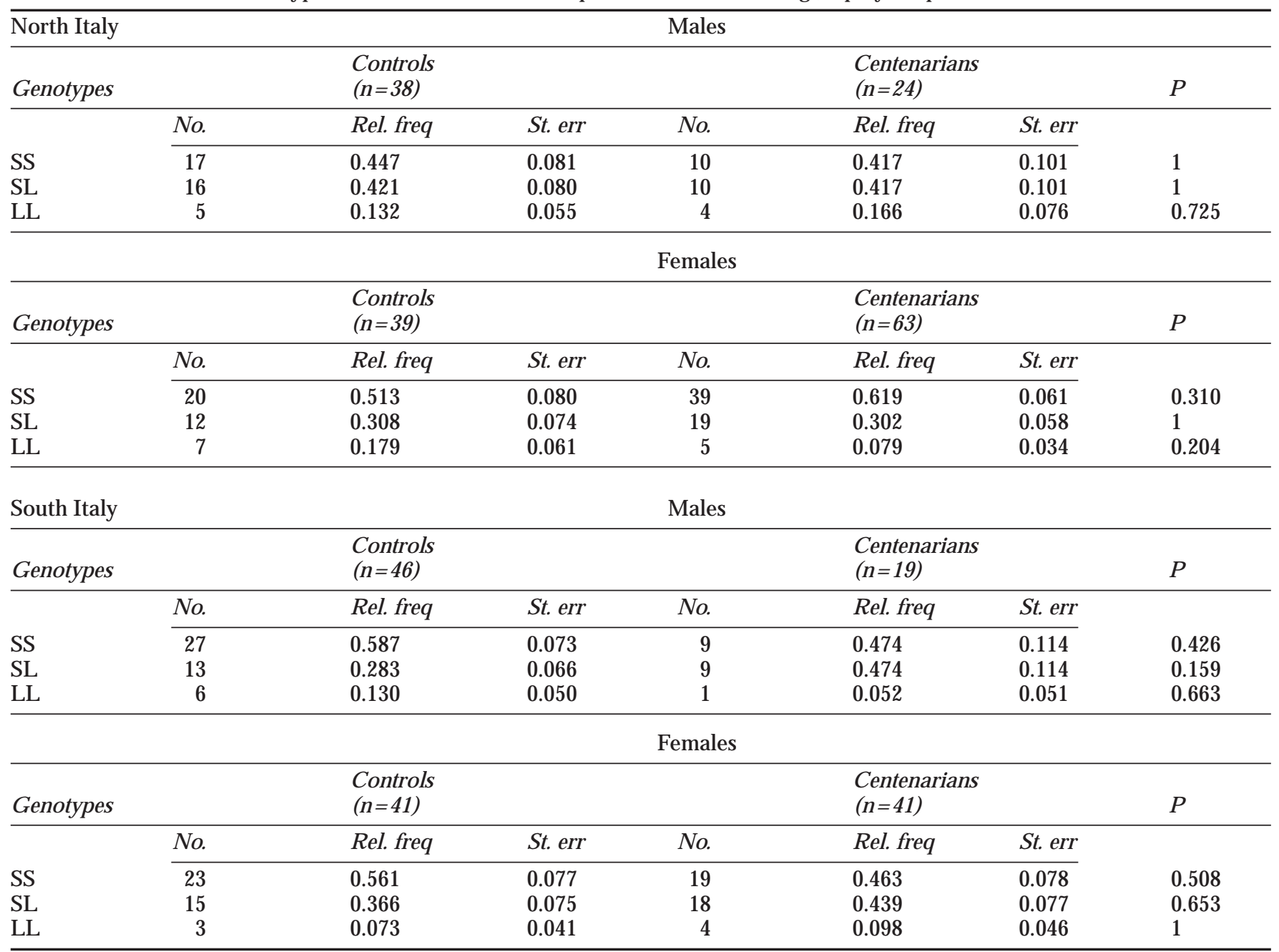

S: alleles 85, 87 and 89; L : alleles 93, 95, 97 and 99. P: probability of falsely rejecting the hypothesis of equal genotype frequency ( $S S$ or $S L$ or $L L$ ) in centenarians and controls $\alpha=0.017$.

i) starting from different frequency patterns in northern and southern Italian controls, the THO genotypic pools attained the same pattern in northern and southern Italian centenarians by means of a hypothetical selection affecting survival;

ii) survival selection throughout THO locus should affect males and females differently.

\section{Discussion}

The aim of the present study was to test whether the variability of four genes controlling fundamental metabolic pathways is associated with human longevity. The approach was the genotypic analysis of individuals selected for longevity and younger people matched for sex and geographic area. G enotypes rather than alleles were considered because of a non-additive variance of the longevity trait $^{26}$ and because $\mathrm{H}$ ardy-Weinberg equilibrium was not fulfilled in the sample of southern I talian male centenarians $(P=0.028)$.

A t present, association studies are a more reliable approach to identify the genes that affect interindividual variability in life-expectancy, but three points should be taken into account. Firstly, the risk of false positive associations caused by confounding heterogeneity factors. To reduce such a risk, both cases and controls examined in the present study were born and resident in the specific geographic area (northern or 
southern Italy) for three generations at least. Furthermore, sex-matched cases and controls were compared, on the assumption that the effect of a certain gene could vary between males and females (as expected for multifactorial traits) according to sexspecific physiological scenarios. Secondly, the age of the control group. U sually people aged 20-60 years are tested as controls with respect to centenarians, since this age range should minimise the risk of case/control overlap. ${ }^{3}$ However, this choice introduces selective criteria for the control group which reduce its randomness. In the present study, whilst a stringent selection was made as to cases (people older than 100 years), the only selection as to controls was the availability of each person to take part in the study. Thirdly, the choice of candidate loci. The loci tested in our study are good candidates, because of their biological role in fundamental metabolic pathways that could be damaged in physiological aging ${ }^{27}$

Neither direct comparisons between genotypes (Table 1, Table 3, Table4) nor three-way analyses revealed significant differences between case/control genotypic pools at REN, PARP, SOD 2 loci. Therefore HUMREN 4, PARP (gt) ${ }_{845 n t}$ and SOD2(c/t) ${ }_{401 n t}$ polymorphisms are not markers of longevity. $\mathrm{O} n$ the other hand positive results were found at the THO locus. The loss of $L L$ genotypes in male centenarians with respect to controls in both southern and northern I taly is evident (Table2), although statistical significance is borderline in northern I talian males when adjustment for multiple comparison is made. In any case, we agree with $\mathrm{R}$ othman ${ }^{28}$ that reducing the type 1 error for null

Table 4 SO D 2 locus. G enotypic numbers and relative frequencies of the SO D 2 (C/T) polymorphism

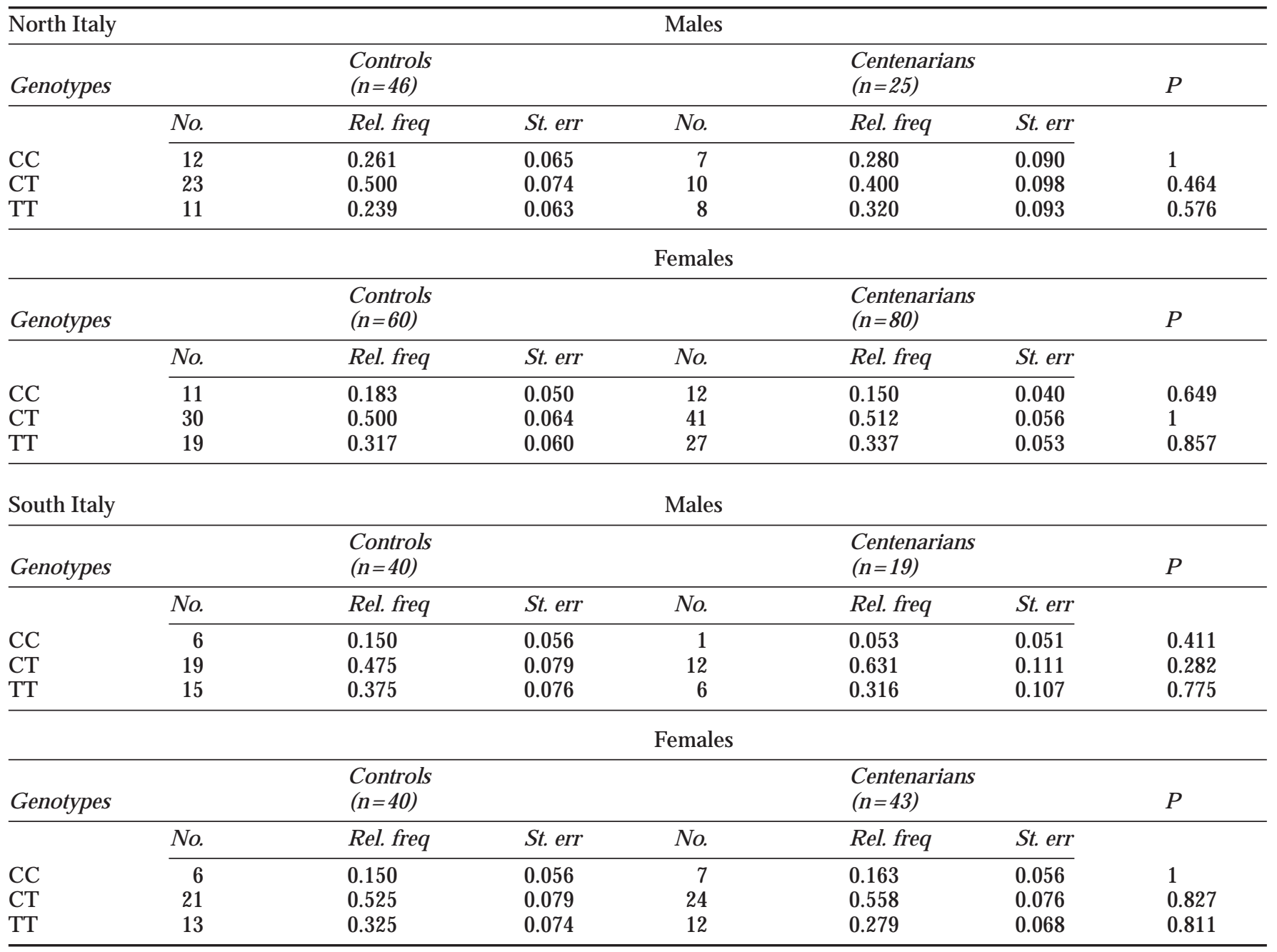

P: probability of falsely rejecting the hypothesis of equal genotype frequency (CC or CT or TT) in centenarians and controls. $\alpha=0.017$. 
associations increases the type II error for those associations that are not null. On the other hand, it is well known that the number of males who survive to very old age is much lower than that of females. If a certain genotype is unfavourable to longevity only (or primarily) in males, a gender gap in longevity should ensue. O ur results suggest that the TH O locus could be one of those which correlate with gender effect in human longevity.

The finding that the HUMTHO1 marker is associated with long life expectancy and that such an effect is sex-related gives rise to two questions. Could a tandem-repeat polymorphic region affect life expectancy? Why does such an effect occur in males but not in females? A s to the first question, HUMTHO 1 lies in intron 1. It was proposed ${ }^{7}$ that secondary structures of the first intron and between first and second introns could affect THO alternative splicings. We might speculate that the variability of HU M THO 1 may play a role in the efficient production of spliced mRNAs. Indeed recent data has shown that the biological role of V NTR alleles of different size may be different. ${ }^{29,30} \mathrm{O} \mathrm{n}$ the other hand, since HUMTHOI and INS-VNTR markers are in linkage-disequilibrium and IN S-V NTR allele frequencies show a sex-specific age-related trend, ${ }^{31}$ it may also be that sex-specific age-related variations of the genotypic pool embrace the entire D NA region comprising both THO and INS loci. In our samples at present, we are analysing further markers occurring in the (11p15.5) DNA region in order to clarify this point. A $s$ to the second question, we must consider that the effect of a gene on a multifactorial trait depends on the physiological background in which the gene is expressed. Therefore, if the age-related physiological scenario changes in males and females differently, the effect of a certain gene on survival could vary between the sexes.

In conclusion, the data here reported shows that the genotypic pools at THO locus differ between male centenarians and male controls, the $L L$ homozygous genotypes being very rare in centenarians. Furthermore, the specificity of the positive association found at the THO locus is validated by the negative findings at RE N, PARP and SOD 2 loci.

\section{Acknowledgements}

The work was financed by Regione Calabria (Progetto Operativo Plurifondo 94-99) by the Italian M inistry of U niversity and Scientific R esearch (40\% and 60\% MURST) by I NRCA (A ncona, Italy) and by the National Research Council, Target Project on A ging $(94,00408$, PF 40$)$.

\section{References}

1 Martin G M : G enetic modulation of the senescent phenotype of Homo sapiens. Exp G erontol 1996; 31: 49-59.

2 Y ashin A I, I achine IA : H ow frailty models can be used for evaluating longevity limits: taking advantage of an interdisciplinary approach. Demography 1997; 34: 31-48.

3 Schachter F, Cohen D, Kirkwood T: Prospects for the genetics of human longevity. Hum Genet 1993; 91: 519-526.

4 Piazza A, Cappello N, Olivetti E, R endine S: A genetic history of I taly. A nn H um G enet 1988; 52: 203-213.

5 Edwards A, Civitello A, H ammond H A, Caskey CT: D NA typing and genetic mapping with trimeric and tetrameric tandem repeats. A m J H um G enet 1991; 49: 746-756.

$6 \mathrm{E}$ dwards A, H ammond $\mathrm{HA}$, J in L, C askey T, Chakraborty $\mathrm{R}$ : Genetic variation at five trimeric and tetrameric tandem repeat loci in four human population groups. G enomics 1992; 12: 241-253.

7 Kobayashi K, Kaneda N, I chinose $\mathrm{H}$ et al: Structure of the human Tyrosine $\mathrm{H} y d r o x i l a s e$ gene: alternative splicing from a single gene accounts for generation of four $\mathrm{mRNA}$ types. J B iochem Tokyo, 1988; 103: 907-912.

8 Polymeropoulos $\mathrm{MH}, \mathrm{X}$ iao $\mathrm{H}, \mathrm{R}$ ath $\mathrm{DS}$, Merril CR: Tetranucleotide repeat polymorphism at the human Tyrosine Hydroxilase gene (TH ). Nucleic A cids Res 1991; 19: 3753.

9 Puers C, Hammond HA, J in L, Caskey T, Schumm JW: Identification of repeat sequence heterogeneity at the polymorphic short tandem repeat locus HUMTHO 1 $(A A G T) n$ and reassignment of alleles in population analysis by using a locus specific allelic ladder. A m J H um G enet 1993; 53: 953-958.

10 M CG innis RE and Spielman R S: Insulin gene 5' flanking polymorphism. Length of class 1 alleles in number of repeat units. D iabetes 1995; 44: 1296-1302.

11 U ndlien DE, B ennet ST, Todd JA et al: Insulin gene region encoded susceptibility to IDDM maps upstream of the insulin gene. D iabetes 1995; 44: 620-625.

12 Kennedy G C, G erman M S, R utter WY: The minisatellite in the diabetes susceptibility locus IDDM 2 regulates insulin transcription. N at G enet 1995; 9: 293-298.

13 Lucassen A, Screaton $G$, Julier C, Elliot T, L athrop $M$, Bell J: Regulation of insulin gene expression by the IDDM associated insulin locus haplotypes. Hum Mol G enet 1995; 4: 501-506.

14 Vafiadis $\mathrm{P}, \mathrm{B}$ ennet ST, Todd JA: Insulin expression in human thymus is modulated by INS-V NTR alleles at the ID D M 2 locus. Nat G enet 1997; 15: 289-292.

15 Pugliese A, Zeller M, Fernandez A J r et al: The insulin gene is transcribed in human thymus and transcription levels correlate with allelic variation at the INS VNTR ID D M 2 susceptibility locus for type 1 diabetes. $N$ at $G$ enet 1997; 15: 293-297.

16 Satoh MS, Lindahl T: R ole of poly(A D P-ribose) formation in DNA repair. Nature 1992; 356: 356-358. 
17 Burkle A, G rube K, Kupper J K: Poly(A D P) ribosylation: its role in inducible DNA amplification and its correlation with the longevity of mammalian species. Exp Clin Immunogenet 1992; 9: 230-240.

18 Grube K, Burkle A: Poly (ADP-ribose) polymerase activity in mononuclear leukocytes of 13 mammalian species correlates with species specific life span. Proc $\mathrm{N}$ atl A cad Sci USA 1994; 99: 11759-11763.

19 Burkle A, Muller M, Wolf I, Kupper JH: Poly (A DP. ribose) polimerase activity in intact or permeabilized leukocytes from mammalian species of different longevity. Mol Cell Biochem 1992; 138: 85-90.

20 Fougerousse $F, M$ eloni $R$, Roudaut $C$, Beckmann J S: $D$ inucleotide repeat polymorphism at the human poly(A DP-ribose) polymerase gene (PPOL). Nucleic A cids Res 1992; 20: 1166.

21 Weisiger RA, Fridovich I: Mitochondrial superoxide dismutase: site of synthesis and intramitochondrial localization. J Biol Chem 1973; 248: 4793-4796.

22 R osenblum J S, G ilula NB, L erner R A : O n signal sequence polymorphisms and disease of distribution. Proc $\mathrm{Nat}$ A cad Sci USA 1996; 93: 4471-4473.

23 Shimoda-M atsubayashi $\mathrm{S}, \mathrm{M}$ atsumine $\mathrm{H}$, Kobayashi $\mathrm{T}$, Nakagawa-H attori $Y$, Shimizu $Y$, M izumo $Y$ : Structural dimorphism in the mitochondrial targeting sequence in the human manganese superoxide dismutase gene. Biochem Biophys Res Comm 1996; 226: 561-565.
24 Weir BS: Genetic data analysis II. Sinauer A ssociates: Sunderland M A, 1996; pp 98-101.

25 Sokal RR, Rohlf FJ: Biometry. Freeman WH \& Co: New York, 1981; pp 747-765.

26 Herskind $A M, M c G$ ue $M, H$ olm NV, Sorensen TIA, $H$ arvald $B$, Vaupel JW: The heritability of human longevity: a population based study of $2872 \mathrm{D}$ anish twin pairs born 1870-1900. H um G enet 1996; 97: 319-323.

27 De Benedictis $G$, Falcone $E$, Rose $G$ et al: DNA multiallelic systems reveal gene/longevity associations not detected by diallelic systems. The APOB locus. Hum G enet 1997; 99: 312-318.

28 Rothman KJ: No adjustments are needed for multiple comparisons. E pidemiology 1990; 1: 43-46.

29 B ennet ST, L ucassen A M , G ough SC L et al: Susceptibility to human type A diabetes at IDDM 2 is determined by tandem repeat variation at the insulin gene minisatellite locus. $\mathrm{N}$ at $\mathrm{G}$ enet 1995; 9: 284-291.

30 O'D onovan MC, Craddock N, Guy C: Involvement of expanded trinucleotide repeats in common diseases. $\mathrm{L}$ ancet, 1996; 348: 1739-1740.

31 Tybjaerg-H ansen A , G erdes L U, O vergaard K, Ingerslev J, Faergeman 0 , N erup J: Polymorphism in 5 ' flanking region of human Insulin gene.. A rteriosclerosis 1990; 10: 372-378. 